\title{
Isolasi dan Uji Aktivitas Antibakteri Senyawa Fenol Ekstrak Etil Asetat Rimpang Jahe Merah (Zingiber officinale Roscoe var. sunti)
}

\section{Isolation and Antibacterial Activity of Phenol Compounds of Ethyl Acetic Extract of Red Zinger (Zingiber officinale Roscoe var. sunti)}

\author{
Lilis Siti Aisyah*, Jasmansyah, Sari Purbaya, dan Temi Resnawati \\ Departemen Kimia, Fakultas Sains dan Informatika, Universitas Jenderal Achmad Yani, \\ Jl. Terusan Jenderal Sudirman, PO BOX 148, Cimahi \\ *E-mail: lies.syarifudin@lecture.unjani.ac.id
}

DOI: https://doi.org/10.26874/jkk.v2i1.23

Received: 23 April 2019, Revised: 29 May 2019, Accepted: 29 May 2019, Online: 31 May 2019

\begin{abstract}
Abstrak
Dalam pengobatan penyakit infeksi, salah satu masalah serius yang dihadapi adalah terjadinya resistensi bakteri terhadap antibiotik yang digunakan. Pencarian senyawa-senyawa antimikroba baru merupakan salah satu kegiatan riset yang penting, karena dilatar belakangi berkembangnya populasi bakteri yang resisten. Sejalan dengan hal tersebut, diperlukan pengembangan obat-obat baru untuk menggantikan obat-obat yang menjadi resisten. Penelitian ini bertujuan untuk mengisolasi senyawa fenol dari ekstrak etil asetat rimpang jahe merah ( $Z$. officinale Roscoe var. sunti), dan menganalisis hasil isolasi menggunakan spektrofotometer UV dan FTIR serta menguji aktivitas antibakteri senyawa fenol terhadap bakteri Escherichia coli dan Staphylococcus aureus. Tahapan isolasi dimulai dengan cara maserasi serbuk dengan pelarut n-heksana kemudian dilanjutkan maserasi menggunakan pelarut etil asetat. Setelah itu ekstrak etil asetat dilakukan pemisahan dan pemurnian senyawa menggunakan metode kromatografi cair vakum (KCV), kromatografi gravitasi yang dipandu dengan kromatografi lapis tipis ( KLT) dan juga kromatografi lapis tipis preparatif (KLTP). Dari hasil isolasi didapat isolat murni, dilakukan uji kemurnian, pengukuran menggunakan spektrofotometer UV dan IR, serta dilakukan uji aktvitas antibakteri. Dari hasil analisis UV dan FTIR, disimpulkan bahwa senyawa yang diperoleh merupakan kelompok senyawa fenol, berupa padatan kuning dan menunjukkan adanya sistem ikatan rangkap terkonyugasi dengan adanya gugus $-\mathrm{OH}, \mathrm{C}=\mathrm{O}, \mathrm{C}=\mathrm{C}$ dan $-\mathrm{CH}$ aromatik. Uji aktivitas antibakteri menunjukkan bahwa konsentrasi hambat minimum (KHM) terhadap bakteri Escherichia coli sebesar 12,5\% dengan konsentrasi bunuh minimum (KBM) sebesar 50\%, sedangkan terhadap bakteri Staphylococcus aureus menunjukkan bahwa konsentrasi hambat minimum (KHM) sebesar 6,3\% dan konsentrasi bunuh minimum (KBM) sebesar $25 \%$.
\end{abstract}

Kata Kunci: Antibakteri, etil asetat, Escherichia coli, ekstrak rimpang jahe merah, Staphylococcus aureus

\section{Abstract}

In the treatment of infectious diseases, one of the serious problems faced is the occurrence of bacterial resistance to the antibiotics used. The search for new antimicrobial compounds is one of the important research activities, because of the background of the development of resistant bacterial populations. In line with this, the development of new drugs is needed to replace drugs that become resistant. This study aimed to isolate phenol compounds from the ethyl acetate extract of red ginger rhizome (Z. officinale Roscoe var. Sunti), and analyze the results of isolation using UV and FTIR spectrophotometers and test the antibacterial activity of phenol compounds to Escherichia coli and Staphylococcus aureus. The isolation stage was started by macerating the powder with $n$-hexane solvent then continued maceration using ethyl acetate solvents. After that the ethyl acetate extract was carried out by separation and 
purification of the compound using the vacuum liquid chromatography (VLC), guided gravity chromatography with thin layer chromatography (TLC) and also preparative thin layer chromatography $(P T L C)$. From the isolation results obtained pure isolates, purity test, measurement using UV and IR spectrophotometers, and antibacterial activity tests. From the results of UV and FTIR analysis, it was concluded that the compounds obtained were groups of phenol compounds, in the form of yellow solids and showed the existence of a double bond system conjugated in the presence of $-\mathrm{OH}$, $C=O, C=C$ and $-C H$ aromatic groups. Antibacterial activity test showed that the minimum inhibitory concentration (MIC) of Escherichia coli bacteria was $12.5 \%$ with a minimum kill concentration (MBC) of 50\%, whereas for Staphylococcus aureus bacteria showed that the minimum inhibitory concentration (MIC) was $6.3 \%$ and minimum kill concentration (MBC) of $25 \%$.

Keywords: Antibacterial, ethyl acetic, Escherichia coli, red zinger extract, Staphylococcus aureus

\section{Pendahuluan}

Penyakit infeksi merupakan penyakit yang umum terjadi pada manusia. Keadaan infeksi ialah cedera selular lokal yang disebabkan oleh keadaan invasi dan multiplikasi dari mikroorganisme [1]. Jumlah korban di seluruh dunia akibat infeksi adalah sekitar 13 juta orang per tahun [2]. Pengobatan klinis untuk menangani penyakit infeksi yaitu dengan penggunaan antibiotik. Efek samping penggunaan antibiotik dapat berupa reaksi alergi, reaksi toksik, serta perubahan biologik dan metabolik pada hospes. Salah satu alternatif untuk menghindari efek samping yang berlebihan maka penggunaan obat tradisional saat ini masih diperlukan, dimana penggunaan obatobat tradisional yaitu berdasarkan pengalaman empiris dan belum dilakukan penelitian maupun percobaan-percobaan secara ilmiah [3].

Indonesia merupakan negara yang terkenal dengan hasil pertanian dan tanaman herbal. Tumbuhan obat yang digunakan oleh masyarakat sebagai bahan baku obat tradisional dikenal dengan etnobotani. Tumbuhan ini mengandung senyawa - senyawa kimia alami, yang disebut senyawa metabolit sekunder [4].

Salah satu tanaman yang mengandung senyawa metabolit sekunder adalah rimpang jahe merah (Z. officinale Roscoe var. sunti). Jahe merah (Z. officinale Roscoe var. sunti) dari famili Zingiberaceae merupakan salah satu rempah rempah penting yang digunakan sebagai bumbumasak, pemberi aroma dan rasa pada makanan serta minuman, industri obat, minyak wangi dan jamu tradisional. Bagian penting dari bahan obat tanaman ini adalah akar yang mempunyai bau aromatik dan rasanya pedas [5].

Beberapa penelitian mengenai jahe merah $(Z$. officinale Roscoe var. sunti) telah banyak dilakukan, Karuppiah dan Rajaram (2012) melakukan penelitian mengenai aktivitas antibakteri dari ekstrak etanol jahe merah ( $Z$. officinale Roscoe var. sunti) terhadap bakteri Staphylococcus aureus, Pseudomonasaeruginosa, Enterococcus faecalis, Klebsiella pneumonia, Proteus mirabilis, Enterococcus cloacae, Bacillus subtilis [6]. Hasil penelitian menunjukkan bahwa rimpang jahe merah ( $Z$. officinale Roscoe var. sunti) memiliki aktivitas antibakteri yang efektif terhadap patogen klinis multi - obat dan dapat digunakan untuk pencegahan penyakit mikrobial, nilai MIC dari ekstrak kasar rimpang jahe relatif tinggi (67,0 ug / mL) terhadap P. Aeruginosa.

Arianti dkk. (2017) melakukan penelitian mengenai uji aktivitas antibakteri terhadap bakteri S. aureus dan E.coli hasilnya menunjukkan bahwa ekstrak etil asetat rimpang jahe merah memberikan efek yang paling baik terhadap pertumbuhan bakteri dengan konsentrasi hambat minimum (KHM) terhadap S. aureus sebesar 6,3\% dan E. coli $25 \%$ dan konsentrasi bunuh minimun (KBM) terhadap S. aureus $25 \%$ dan E. coli $50 \%$ [7].

Penelitian ini bertujuan memperoleh senyawa fenol dari ekstrak etil asetat jahe merah ( $Z$. officinale Roscoe var. sunti) dan menganalisis senyawa tersebut menggunakan spektrofotometer UV dan FTIR serta menguji aktivitas antibakteri isolat fenolat dengan metode mikro dilusi terhadap bakteri Escherichia coli dan Staphylococcus aureus.

\section{Metode Penelitian}

\subsection{Bahan dan Alat}

Bahan yang digunakan pada penelitian ini adalah jahe merah (Z. officinale Roscoe var. sunti) segar, akuades, n-heksana $\left(\mathrm{C}_{6} \mathrm{H}_{14}\right)$ redestilat, etil asetat $\left(\mathrm{CH}_{3} \mathrm{COOC}_{2} \mathrm{H}_{5}\right)$ redestilat, metanol $\left(\mathrm{CH}_{3} \mathrm{OH}\right)$ redestilat, metilen klorida (MTC) redestilat, aseton $\left(\mathrm{C}_{3} \mathrm{H}_{6} \mathrm{O}\right)$ redestilat. plat KLT (TLC Silica gel 60 F254), silika gel60 G (230 $400 \mathrm{mesh})$, silika gel60 $(0,2-0,5 \mathrm{~mm})$, antibiotik siprofloxaxin, Biakan murni E.coli, Biakan murni 
S. aureus, Medium Mueller Hinton agar (MHA), Dimetil Sulfoksida (DMSO).

Alat - alat yang digunakan adalah Spektroskopi Ultraviolet Hewlett Packard 8453, Spektroskopi Inframerah merk Shimadzu Tipe Prestige-21, alat gelas laboratorium, Bunsen, blender merk Philips, Rotary evaporator merk Heidolph Laborata 4000 type Heizbad W, pisau, maserator, spidol, batang pengaduk, pinset, hot plate merk Labtech type LMS 1003, chamber, kertas pembungkus, inkubator merk ESCO type CelMate ${ }^{\circledR C O} 2$, Mikropipet Acura 815 Socorex, oven merk Memmert type UN55, pisau, ose, spirtus, cawan petri, mikrotiter plat.

\subsection{Cara Kerja}

\section{Ekstraksi}

Sebanyak 575 gram sampel serbuk kering rimpang jahe merah ditimbang, kemudian dimaserasi dengan $\mathrm{n}$ - heksana selama 3 × 24 jam. Setiap 24 jam pelarut diganti dengan yang baru hingga filtrat tidak berwarna. Residu yang dihasilkan dimaserasi kembali dengan pelarut etil asetat selama 3 x 24 jam. Setiap 24 jam pelarut diganti dengan yang baru hingga filtrat tidak berwarna. Filtrat kemudian dipisahkan dengan menggunakan rotari evaporator hingga diperoleh ekstrak kental etil asetat sebanyak $15 \mathrm{~g}$.

\section{Pemisahan dengan kromatografi Kolom}

Sebelum dilakukan kromatografi kolom dilakukan terlebih dahulu penentuan eluen menggunakan Kromatografi Lapis Tipis (KLT) dengan fasa diam silika gel 60 GF254 dan fasa gerak campuran eluen dengan perbandingan tertentu, lalu dilakukan Kromatografi Cair Vakum (KCV). Ekstrak etil asetat sebanyak $15 \mathrm{~g}$ dipisahkan secara gradien dengan kromatografi cair vakum dengan menggunakan pelarut nheksana, etil asetat dan metanol secara bergradien mulai dari n-heksan $100 \%$ sampai etil asetat 100 $\%$, dan metanol $100 \%$ sehingga di peroleh 18 fraksi, fraksi 7 dan 8 digabung sehingga hasilnya diperoleh 17 fraksi. Selanjutnya hasil KCV dilakukan KLT untuk pengelompokkan fraksi berdasarkan pola noda yang sama kemudian disatukan menjadi suatu fraksi yang besar.

\section{Identifikasi Fenol}

Fraksi yang didapat kemudian dilakukan KLT dan disemprot menggunakan pereaksi Besi (III) klorida. KLT tersebut dimasukkan dalam oven dengan suhu $110{ }^{\circ} \mathrm{C}$ selama 5 menit. Noda KLT selanjutnya dilihat pada lampu UV $254 \mathrm{~nm}$.
Pemisahan dengan Kromatografi Preparatif (KLTP)

Kromatografi preparatif dilakukan terhadap fraksi yang positif fenol untuk mendapatkan isolat fenol yang murni. Sebelumnya lakukan KLT untuk menentukan eluen yang baik. Kromatografi preparatif dilakukan dengan plat silika gel GF254 ukuran $10 \times 10 \mathrm{~cm}$ dengan ketebalan $0,2 \mathrm{~cm}$. Setelah fraksi positif fenol dielusi, dilakukan pengerokan pita-pita dan selanjutnya direndam menggunakan aseton yang melarutkan isolat fenol.

\section{Uji Kemurnian}

Hasil kromatografi kolom diuji secara KLT dengan menggunakan beberapa campuran eluen. Bila tetap menghasilkan noda satu maka fraksi tersebut dapat dikatakan sebagai isolat relatif murni secara KLT.

\section{Identifikasi UV-Vis dan IR}

Analisis UV-Vis digunakan untuk menentukan sistem terkonjugasi yang memiliki atau terikat pada suatu gugus fungsi. Analisis IR digunakan untuk menentukan gugus fungsi.

\section{Uji Aktivitas Antibakteri}

Isolat murni yang dihasilkan kemudian dilakukan uji aktivitas antibakteri terhadap bakteri $S$. aureus dan bakteri $E$. coli dengan menggunakan metode dilusi cair untuk mengetahui konsentrasi hambat minimum (KHM) dan konsentrasi bunuh minimum (KBM) dengan melakukan pemindah tanaman dari masing-masing kolom sampel uji yang tidak memperlihatkan adanya pertumbuhan mikroba pada uji KHM sebanyak 1 ose. Diinokulasikan ke cawan petri yang sudah berisi media MHA. Inkubasi pada suhu $37^{\circ} \mathrm{C}$ selama 1824 jam. Dilihat apakah terjadi pertumbuhan bakteri atau tidak. Tidak adanya pertumbuhan bakteri menunjukkan nilai konsentrasi bunuh minimum.

\section{Hasil dan Diskusi}

\subsection{Ekstraksi}

Rimpang jahe merah kering, haluskan sampai menjadi serbuk rimpang jahe merah (mesh 40 60). Penghalusan sampel bertujuan untuk mempermudah sampel tercampur dalam pelarut, karena semakin halus sampel maka semakin luas permukaan sentuh antara pelarut dengan sampel, sehingga senyawa yang berada pada sampel akan tertarik pelarut dengan baik. Serbuk dari rimpang jahe merah ( $Z$. officinale Roscoe var. sunti) diperoleh sebanyak $575 \mathrm{~g}$ (11,5\%). Sebanyak 575 
g serbuk rimpang (Z. officinale Roscoe var. sunti) dimaserasi menggunakan n-heksana selama 1 x 24 jam. Maserasi dilakukan secara berulang hingga filtrat terekstraksi secara maksimal.

Pelarut yang digunakan pada proses maserasi ini adalah n-heksana. n-Heksana digunakan saat maserasi bertujuan untuk mengekstraksi senyawasenyawa yang bersifat non-polar seperti lemak, terpena, klorofil, xantofil dan lain-lain [8].

Residu sisa maserasi dengan n-heksana selanjutnya dimaserasi kembali dengan etil asetat. Pelarut semi polar yang digunakan adalah etil asetat. Pelarut ini memiliki tingkat kepolaran lebih tinggi dibandingkan $\mathrm{n}$-heksana dengan tingkat kepolaran sebesar 6,0 [8]. Senyawa yang akan tertarik oleh pelarut ini adalah senyawa semi polar diantaranya alkaloid, flavonoid dan terpenoid [7]. Maserat yang diperoleh di uapkan dengan alat penguap vakum pada suhu $40{ }^{\circ} \mathrm{C}$, sehingga diperoleh ekstrak kental etil asetat sebanyak 11,5 gram.

\subsection{Pemisahan dengan kromatografi kolom}

Ekstrak kental etil asetat dipisahkan dengan menggunakan kromatografi cair vakum kolom didapatkan 17 fraksi (Gambar 1). Fraksi yang dihasilkan di KLT, tujuannya adalah untuk melihat nilai $R_{f}$ yang sama digabungkan.

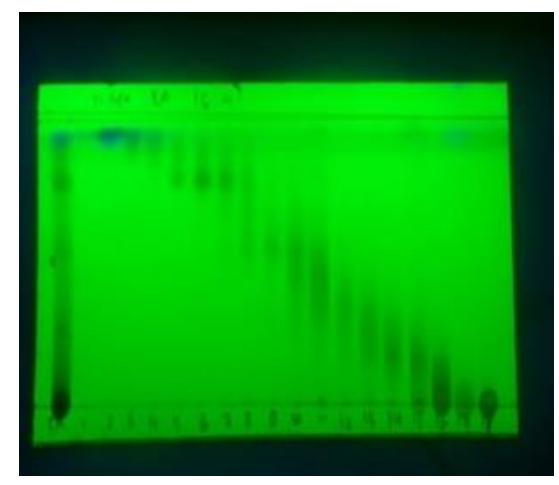

Gambar 1. KLT fraksi hasil KCV

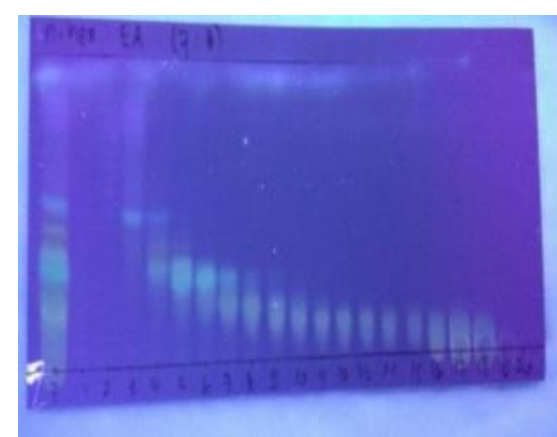

Gambar 2. KLT fraksi hasil KG fraksi 7
Fraksi 7 dilakukan pemisahan dengan metode kromatografi kolom dengan eluen $\mathrm{n}$ - heksana : etil asetat secara bergradien sehingga diperoleh 19 fraksi (Gambar 2).

\subsection{Identifikasi Fenol}

Identifikasi fenol dilakukan dengan penambahan $\mathrm{FeCl}_{3}$ terhadap fraksi 7 untuk mengetahui adanya fenol. Senyawa fenol apabila disemprot dengan $\mathrm{FeCl}_{3}$ akan tampak noda berwarna kuning apabila dilihat di bawah UV 254 $\mathrm{nm}$. Reaksi identifikasi fenol diperlihatkan pada Gambar 3.

Fenol

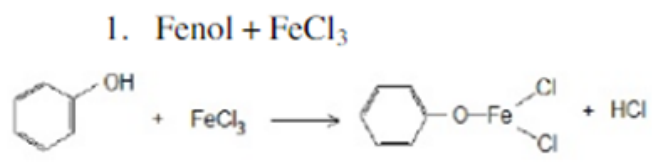

Gambar 3. Reaksi identifikasi fenol menggunakan $\mathrm{FeCl}_{3}$

\subsection{Pemisahan dengan Kromatografi Preparatif}

Uji fenol pada fraksi 7 dengan KLT menggunakan $\mathrm{n}$-heksana : etil asetat (8:2) didapatkan noda fenol yang berwarna kuning berdekatan dengan noda yang lain sehinga bila dipisahkan senyawa target akan terbawa senyawa yang lain, sehingga dilakukan KLTP dengan mengerok silika gel pada daerah pita yang positif fenol. Hasil kromatografi preparative ditunjukkan pada Gambar 4. Silika hasil pengerokan kromatografi preparative selanjutnya dilakukan perendaman menggunakan aseton sehingga didapatkan cairab berwarna kekuningan. Setelah didapat isolate fenol selanjutnya dilakukan uji kemurnian.
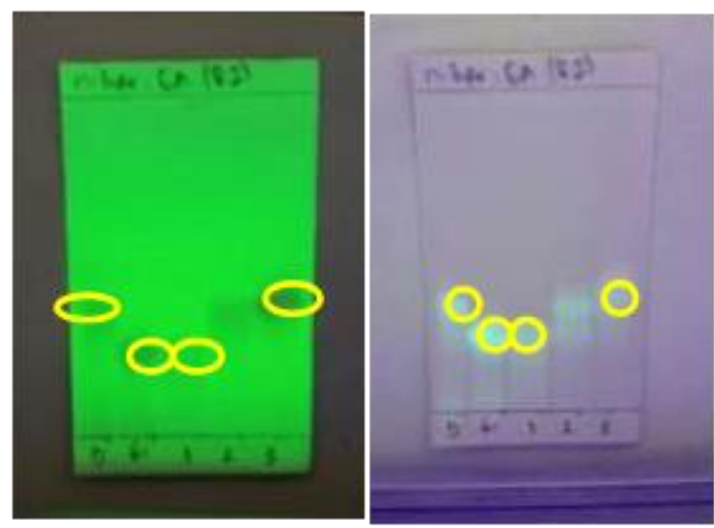

Gambar 4. Hasil kromatografi preparatif 


\subsection{Uji Kemurnian}

Uji Kemurnian isolat fenol dilakukan dengan menggunakan metode KLT dengan berbagai eluen. Eluen yang dipakai adalah n-heksana : metilen klorida (1:9), n-heksana : etil asetat (8:2), metilen klorida : etil asetat (9:1). Uji kemurnan ditunjukkan seperti pada Gambar 5.

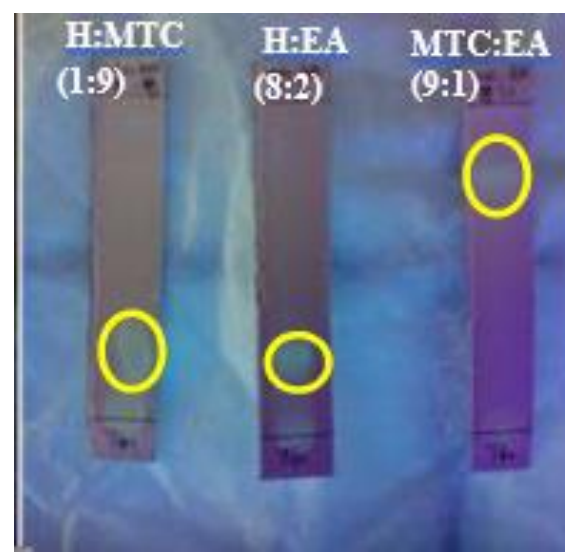

Gambar 5. KLT isolat fenol dengan 3 eluen yang berbeda

Hasil KLT pada uji kemurnian dengan tiga eluen yang berbeda, setelah disemprot dengan $\mathrm{FeCl}_{3}$ didapatkan satu noda berwarna kuning yang membuktikan bahwa isolate yang diperoleh merupakan isolat murni.

\subsection{Analisis dengan UV-Vis dan IR}

Pada pengukuran spektrum UV - Vis senyawa 1 diperoleh 2 puncak dengan panjang gelombang $280 \mathrm{~nm}$ (pita I) dan $233 \mathrm{~nm}$ (pita II) (Gambar 6). Pada pita I menunjukkan adanya gugus karbonil $(\mathrm{C}=\mathrm{O})$, hal ini didukung dari analisis spektroskopi IR yang menunjukkan bahwa senyawa 1 memiliki gugus fungsi $\mathrm{C}=\mathrm{O}$ pada daerah bilangan gelombang $1.735,93 \mathrm{~cm}^{-1}$.

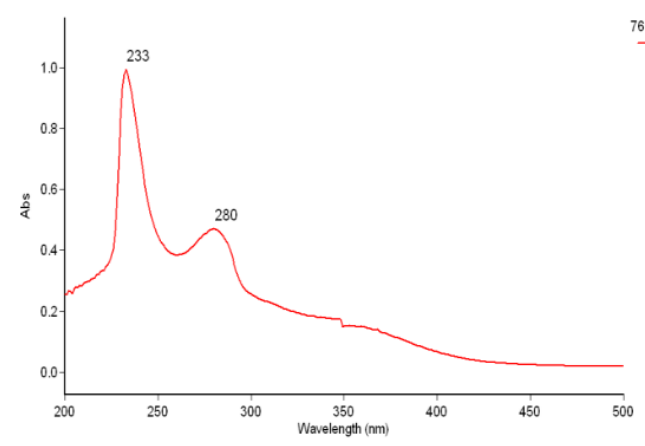

Gambar 6. Spektrum UV isolat fenol

Pada pita I $(233 \mathrm{~nm})$ mengindikasikan adanya senyawa aromatik dan didukung dengan spektrum IR pada bilangan gelombang 1.516,05 $\mathrm{cm}^{-1}$ yang menunjukkan adanya ikatan $\mathrm{C}=\mathrm{C}$ aromatik. Identifikasi menggunakan pereaksi geser pada senyawa 1 dengan adanya penambahan $\mathrm{NaOH}$ (Gambar 7) menunjukkan bahwa adanya pergeseran batokromik pada panjang gelombang $424 \mathrm{~nm}$ menunjukkan bahwa adanya gugus $\mathrm{OH}$ bebas, hal ini didukung dari analisis spektroskopi IR yang menunjukkan bahwa senyawa 1 memiliki gugus $\mathrm{OH}$ pada daerah bilangan gelombang $3.429,43 \mathrm{~cm}^{-1}$.

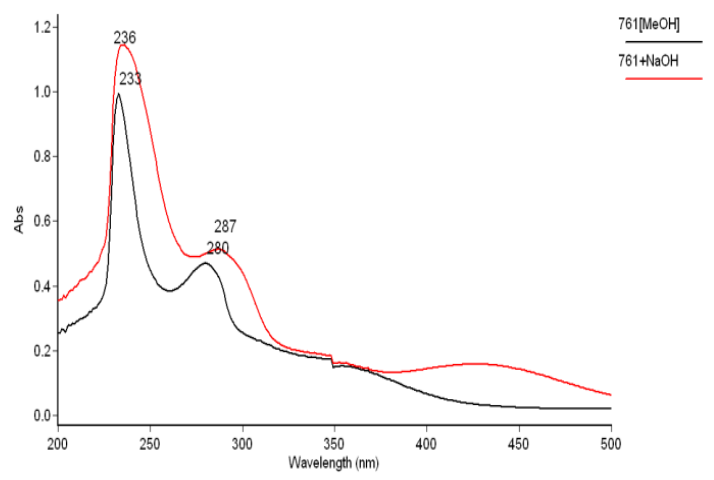

Gambar 7. Spektrum UV isolat fenol dengan penambahan $\mathrm{NaOH}$

Analisa spektroskopi IR digunakan untuk mengidentifikasi adanya gugus fungsi dalam suatu senyawa. Identifikasi gugus fungsi dapat ditunjukkan oleh serapan khas pada panjang gelombang tertentu, yang merupakan hasil transisi antara tingkat energi getaran (vibrasi) dari setiap interaksi atom - atom dalam suatu molekul, baik berupa bending (lentur) ataupun stretching (regang).

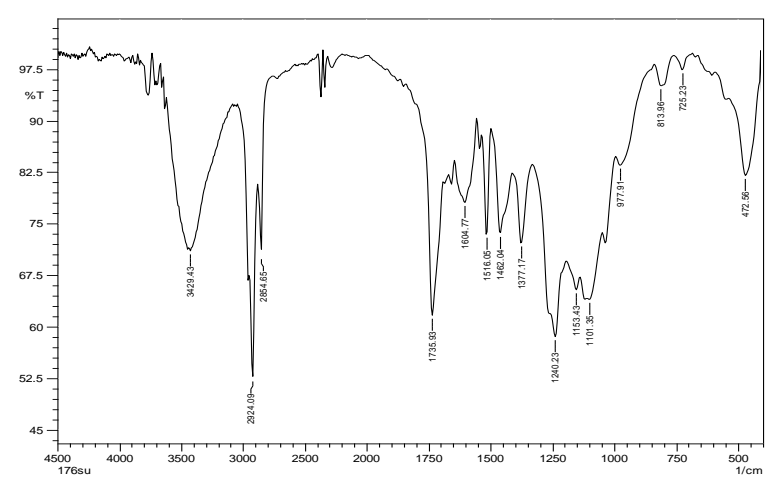

Gambar 8. Spektrum IR isolat fenol rimpang jahe merah

Spektrum IR (Gambar 8) yang dihasilkan menyatakan bahwa pada daerah bilangan gelombang 3.429,43 $\mathrm{cm}^{-1}$ menunjukkan gugus hidroksil $(-\mathrm{OH})$ dimana serapan pita ini berada pada daerah diantara $3300-3500 \mathrm{~cm}^{-1}$ yang didukung dengan spektrum antara $\quad 1200-1400$ 
$\mathrm{cm}^{-1}$ yang mengindikasikan adanya ikatan $\mathrm{C}-\mathrm{O}$ dengan intensitas pita yang lemah.

Pita tajam dengan intensitas kuat pada daerah bilangan gelombang 2.924,09 $\mathrm{cm}^{-1}$ merupakan uluran gugus $\mathrm{C}-\mathrm{H}$ aromatik. Selain ikatan $\mathrm{C}-\mathrm{H}$ aromatik, kemungkinan isolat juga mengandung $\mathrm{C}-\mathrm{H}$ alifatik yang ditandai dengan munculnya serapan dengan intensitas pada daerah bilangan gelombang $2.854,65 \mathrm{~cm}^{-1}$.

Pada daerah bilangan gelombang 1.753,93 $\mathrm{cm}^{-1}$ menunjukkan adanya gugus karbonil $(\mathrm{C}=\mathrm{O})$, serapan pada daerah gelombang $1.462,04 \mathrm{~cm}^{-1}$ dan $1.516,05 \mathrm{~cm}^{-1}$ merupakan serapan yang disebabkan oleh adanya vibrasi ikatan $\mathrm{C}=\mathrm{C}$. Hal ini juga diperkuat oleh adanya serapan pada bilangan gelombang $977,91 \mathrm{~cm}^{-1}, 813,96 \mathrm{~cm}^{-1}$, $725,23 \mathrm{~cm}^{-1}$ yang mengindikasikan adanya tekuk $=\mathrm{CH}$.

Dugaan bahwa hasil isolat merupakan senyawa fenol dimana gugus benzen mengikat satu gugus - $\mathrm{OH}$ dengan intensitas melebar dan tajam dengan serapan pada daerah gelombang $3.429,43 \mathrm{~cm}^{-1}$ dan $1.377,17 \mathrm{~cm}^{-1}$ dan diperkuat gugus fungsi $-\mathrm{OH}, \mathrm{C}=\mathrm{C}, \mathrm{C}=\mathrm{O}, \mathrm{C}-\mathrm{H}$ aromatik. Hasil tersebut didukung dengan adanya data UVVis. Data UV-Vis mengindikasikan adanya pita I dan pita II, maka isolat tersebut mengandung ikatan rangkap, sehingga terlihat adanya konyugasi yang menyebabkan terjadinya pertambahan serapan pada pita.

\subsection{Uji Aktivitas Antibakteri Senyawa 1}

Uji antibakteri isolate fenol dilakukan terhadap bakteri S. aureus dan E. coli yaitu dengan menggunakan metode mikrodilusi cair. Metode ini dipilih karena uji ini memberikan hasil kuantitatif yang menunjukkan jumlah antibakteri yang dibutuhkan untuk mematikan bakteri [9]. Isolat fenol dilakukan pengenceran dengan menggunakan DMSO. Pelarut ini digunakan karena tidak berpengaruh terhadap aktivitas antimikroba. Selain itu, DMSO juga direkomendasikan sebagai pelarut komponen organik yang baik [10].

Penelitian ini digunakan kontrol positif antibiotik siprofloxaxin dan kontrol negatif pelarut DMSO. Antibiotik siprofloxaxin dipilih sebagai kontrol positif karena antibiotik ini sensitif terhadap bakteri Gram positif dan negatif.

Tabel 1 menunjukkan bahwa kontrol positif menggunakan antibiotik siprofloksasin mampu menghambat bakteri pada konsentrasi (KHM) 19,5\% dan memiliki konsentrasi bunuh minimum (KBM) sebesar 3,9\%. Sedangkan untuk kontrol negatif pelarut DMSO tidak berpengaruh terhadap aktivitas antimikroba.

Tabel 1. Hasil dari uji aktivitas antibakteri

\begin{tabular}{ccccc}
\hline \multirow{2}{*}{ No } & \multirow{2}{*}{ Sampel } & Bakteri & \multicolumn{2}{c}{ Hasil Uji } \\
\cline { 4 - 5 } & & Uji & $\begin{array}{c}\text { KHM } \\
(\%)\end{array}$ & $\begin{array}{c}\text { KBM } \\
(\%)\end{array}$ \\
\hline 1. & Isolat fenol & S. aureus & 6,25 & 25 \\
2. & E. coli & 12,50 & 50 \\
3. & siprofloksasin & & 19,5 & 3,9 \\
& DMSO & & 0 & 0 \\
\hline
\end{tabular}

Isolat fenol menunjukkan bahwa senyawa ini memiliki aktivitas antibakteri dengan konsentrasi hambat minimum (KHM) sebesar 6,25\% dan konsentrasi bunuh minimum (KBM) sebesar 25\% terhadap bakteri $S$. aureus. Sedangkan terhadap bakteri E. coli memiliki konsentrasi hambat minimum (KHM) sebesar 12,50\% dan konsentrasi bunuh minimum (KBM) sebesar 50\%.

\section{Kesimpulan}

Berdasarkan hasil penelitian dapat disimpulkan bahwa isolat fenol ekstrak etil asetat rimpang jahe merah ( $Z$. officinale Roscoe var. sunti) berupa padatan kuning diprediksi senyawa turunan fenol, memiliki aktivitas antibakteri dengan konsentrasi hambat minimum (KHM) sebesar 6,25\% dan konsentrasi bunuh minimum (KBM) sebesar 25\% terhadap bakteri S. aureus sedangkan terhadap bakteri $E$. coli memiliki konsentrasi hambat minimum (KHM) sebesar $12,50 \%$ dan konsentrasi bunuh minimum (KBM) sebesar $50 \%$.

\section{Daftar Pustaka}

[1] Dorland N. Kamus Kedokteran Dorland. XXIX. Jakarta: EGC; 2002.

[2] Cowan MK. Microbiology: a sistems approach. Third. New York: Mc Graw Hill; 2012.

[3] Setiabudy R. Antimikroba: Dalam Farmakologi dan Terapi. Edisi V. Jakarta: Balai Penerbit FKUI; 2007.

[4] Dorli. Potensi Tumbuhan Obat di Indonesia dalam Pengembangan Industri Agromedis. Institut Pertanian Bogor; 2005.

[5] Siswanto, Widyastuti Y. Penanganan Hasil Panen Tanaman Obat Komersial. Jakarta: Panebar Swadaya; 2004.

[6] Karuppiah P, Rajaram S. Antibacterial effect of Allium sativumcloves and Zingiber officinalerhizomes against multiple-drug resistant clinical pathogens. Pac J Trop Biomed. 2012. 2(8):597-601.

[7] Arianti EW, Aisyah SL, Jasmansyah. Uji 
Aktivitas Antibakteri Ekstrak Jahe Merah (Zingiber officinale Roscoe var. sunti) terhadap Bakteri Staphylococcus aureus dan Escheririchia coli. Universitas Jenderal Achmad Yani; 2017.

[8] Stahl E. Thin Layer Chromatography a Laboratory Handbook. Second. Tokyo: Toppan Company Limited; 1969.
[9] Brook GF. Mikrobiologi Kedokteran. XXIII. Hartanto H, editor. Jakarta: EGC; 2001.

[10] Carey FA, Sundberg RJ. Advance Organic Chemistry. Fifth. Virginia: Springer; 2007. 